\title{
Re-Scaling of Metropolitan Governance in Germany
}

\author{
Karsten Zimmermann ${ }^{1}$
}

Received: 26 November 2015 / Accepted: 30 January 2017 / Published online: 7 February 2017

(c) Springer-Verlag Berlin Heidelberg 2017

\begin{abstract}
Germany lacks a systematic nation-wide approach for the governance of metropolitan regions. We observe a considerable variety of institutional solutions for the governance of metropolitan affairs. In particular since the 1990s many initiatives have blossomed at different scales giving different weight to economic development, infrastructure planning, spatial planning or waste management. Therefore, the German federal state can be seen as a laboratory for metropolitan governance with a few outstanding cases and some less successful ones. However, the current situation calls for more effective metropolitan governance in most of the German metropolitan regions. The article gives an historical overview, describes recent trends and illustrates four cases in more detail. The emergence of multi-scaled arrangements where different forms of governance function on different spatial scales seems to be the most recent pattern in Germany. The outlook remains unclear.
\end{abstract}

Keywords Metropolitan governance - Germany · planning $\cdot$ scaling

\section{Re-Scaling stadtregionaler Planung in Deutschland}

Zusammenfassung Deutschland verfügt über keine national einheitliche Politik für die Organisation stadt-regionaler Politik. Vielmehr können wir seit Jahrzehnten eine große

Prof. Dr. Karsten Zimmermann

karsten.zimmermann@tu-dortmund.de

1 Fakultät Raumplanung, Technische Universität Dortmund, August-Schmidt-Straße 10, 44227 Dortmund, Germany
Vielfalt an Organisationsformen für die Bewältigung von Stadt-Umland-Problemen beobachten. Insbesondere seit den 1990er-Jahren sind viele neue Initiativen und Organisationsformen auf verschiedenen räumlichen Ebenen hinzugekommen (Stadtregion, Metropolregion), die zudem unterschiedliche Inhalte wie die Wirtschaftsförderung, die Raum- und Infrastrukturplanung oder die Abfallwirtschaft einschließen. Deutschland kann aufgrund dieser Vielfalt als Labor stadtregionaler Planung und Politik mit einigen vielversprechenden Fällen gelten. Es finden sich aber auch weniger erfolgreiche Fälle. Allerdings zeigt die aktuelle Situation, dass durchaus nach effektiveren Formen der Koordination gesucht wird. Der Beitrag zeichnet die historische Entwicklung stadtregionaler Planung und Politik in Deutschland nach, geht auf aktuelle Trends ein und erläutert die jüngsten Entwicklungen anhand von vier Fällen. Es zeigt sich, dass die Herausbildung verschiedener räumlicher Ebenen (Scales) der Kooperation in nahezu allen Fällen beobachtet werden kann. Die zukünftige Entwicklung im Hinblick auf die Etablierung effektiverer Formen der Kooperation ist jedoch nicht gesichert.

Schlüsselwörter Metropolregion - Governance · Deutschland $\cdot$ Planung $\cdot$ Scaling

\section{Introduction}

The history of metropolitan governance in Germany goes back to the early years of the last century. It was in the period from 1910 to 1920 when metropolitan solutions for infrastructure planning, settlement development and the protection of green spaces were discussed in the rapidly growing industrial agglomerations. In those days, Berlin (1916) and the Ruhr area (1920) were exemplary cases 
of different ways of organizing metropolitan politics and planning. While in Berlin a regional city (Groß-Berlin) was realized through the annexation of the smaller municipalities contiguous with the core city, in the Ruhr area an association of municipalities was created. Notwithstanding the volatility of the last century, a stable pattern for metropolitan governance then emerged in the Ruhr area and elsewhere in Germany. The creation of inter-municipal associations (kommunale Zweckverbände or Regionalverbände) is still the instrument most frequently used for the organization of public services and planning functions in metropolitan areas (Fürst/Klinger/Knieling et al. 1990; Heinelt/Zimmermann 2011; Zimmermann 2014). As will be shown in the remainder of this article, metropolitan governance in Germany is less prone to dynamic changes than in many other countries, as illustrated by the recent discussions and legal reforms seen in Italy, the UK, Poland and France, where new layers of metropolitan policymaking and planning have been created by nationwide laws (see Shaw/Tewdwr-Jones (2017), Geppert (2017), Fedeli (2017), Krukowska/Lackowska (2017); in this issue). What we observe in Germany is the continuous and flexible adaptation of existing legal frameworks and institutions. The 1990s brought some changes as the issue of involving private actors gained prominence and new formats for the cooperation of public and private actors were implemented in several regions. However, with a few exceptions, no major reforms took place. The German case illustrates a preference for flexible and context-sensitive institutional solutions but no nationwide strategy (Fürst 2005; Heinelt/ Zimmermann 2011). A recent joint initiative by the 16 states and federal government is an exception and is described in detail in Section 4. But even this initiative cannot be considered a reconfiguration of the formal arrangements in Germany. Hence, the effectiveness of metropolitan governance, understood here as the enhanced and stable coordination of municipalities as well as private actors, depends on the institutional solution found in each region and the policies addressed. This decentralized and non-uniform way of dealing with metropolitan governance is not considered problematic in Germany as it allows for local initiatives to solve difficulties - or not. Thus even in the same region huge differences exist between the metropolitan governance of public transport, regional planning and economic development.

The most notable observation in Germany, one that needs to be highlighted against the experience of the other countries presented in this special issue, is the emergence of several regional scales of governance in quite a few of the German metropolitan regions. These added scales are the result of various political developments such as the introduction of the European Metropolitan Regions as a new informal layer of metropolitan politics that refers to larger metropolitan regions (instead of smaller city regions). The emergence of these new scales can best be described and explained by referring to the concept of politics of scale (Brenner 2004; Swyngedouw 2004; Keil/Mahon 2009; see Zimmermann/Getimis (2017); in this issue). Politics of scale is described as a process where "diverse social forces actively struggle to reorganize the functions, organizational embodiments, and/or interconnections among spatial scales" (Brenner 2009: 45). Furthermore, we agree with Keil and Mahon (2009: 4) that "rescaling involves a complex, highly contested reconfiguration of interscalar arrangements, including the invention of new scales of action and emancipation".

It is the purpose of this paper to describe these developments in Germany against the theoretical frame of rescaling. The paper gives a short introduction to the German system of spatial planning and local government (Section 2) and a historical overview of metropolitan governance in Germany (Section 3). The more recent trends of re-scaling are described in Section 4 and illustrated in more detail by four cases in Section 5. The final section concludes with discussion of the uneven emergence of several scales of governance in metropolitan regions, a development that seems to be a distinguishable trend in Germany.

\section{Institutional Framework}

In the German federation the Länder (states) have almost total responsibility for organizing local and regional politics. The local level is made up of municipalities as institutions of local self-government and the counties as the second tier of local self-government (see Table 1). The status of local self-government is guaranteed by the German Basic Law. Regions exist in formal terms only as planning regions and as districts (Regierungsbezirke). Government offices of the regions that are regional branches of the state governments administer the districts but are not institutions of local selfgovernment. In some states such as Hesse or North RhineWestphalia, the governments of the regions are, besides many other tasks, responsible for statutory regional planning (but see the case of the Ruhr area below). Many other states have created mono-functional inter-municipal associations responsible for statutory regional planning (Planungsverbände). While in some metropolitan regions the statutory planning region coincides - more or less - with the functionally interdependent area, no particular institutional format for metropolitan governance exists nor is it compulsory for municipalities to cooperate or create metropolitan institutions (Fürst 2005; Heinelt/Razin/Zimmermann 2011). However, in most of the metropolitan areas municipalities have created formal inter-municipal associations for various tasks such as waste management, public transport, tourism or land-use planning. All state governments encourage and 
Table 1: The German system of multi-level governance (grey indicates the realm of metropolitan governance)

\begin{tabular}{|c|c|c|}
\hline & Function in Spatial Planning & $\begin{array}{l}\text { Relevance for Metropolitan } \\
\text { Governance }\end{array}$ \\
\hline \multicolumn{3}{|l|}{ Realm of the state } \\
\hline Federal Government & $\begin{array}{l}\text { National law on Spatial Planning } \\
\text { (Framework law) } \\
\text { National Building Code } \\
\text { National Guidance (together with the } \\
\text { states, coordinated by Standing } \\
\text { Conference of Federal and State } \\
\text { Ministers responsible for Spatial } \\
\text { Planning) }\end{array}$ & $\begin{array}{l}\text { Incentives (funding of pilot projects) } \\
\text { Initiative European Metropolitan } \\
\text { Regions (EMR, together with the } \\
\text { states) }\end{array}$ \\
\hline States (Länder) & $\begin{array}{l}\text { State laws on spatial planning } \\
\text { State plans }(1: 100,000 / 1: 300,000) \\
\text { (GOR in some states responsible for } \\
\text { regional planning) }\end{array}$ & $\begin{array}{l}\text { Legal framework (municipal code) and } \\
\text { supervision }\end{array}$ \\
\hline \multicolumn{3}{|l|}{$\begin{array}{l}\text { Government offices of the regions } \\
\text { (GOR) }\end{array}$} \\
\hline $\begin{array}{l}\text { Regional planning bodies (with } \\
\text { participation of counties and } \\
\text { municipalities) }\end{array}$ & $\begin{array}{l}\text { Regional plans }(1: 50,000) \\
\text { (Regional land use plan in } \\
\text { Frankfurt/Rhine-Main) }\end{array}$ & $\begin{array}{l}\text { In urban regions regional planning } \\
\text { often done by inter-municipal } \\
\text { associations }\end{array}$ \\
\hline \multicolumn{3}{|c|}{ Realm of local self-government } \\
\hline $\begin{array}{l}\text { Counties (second tier of local } \\
\text { government) }\end{array}$ & & \multirow{2}{*}{$\begin{array}{l}\text { Inter-municipal associations for public } \\
\text { services (waste management, public } \\
\text { transport, tourism, etc.) } \\
\text { Single or multi-purpose associations }\end{array}$} \\
\hline Municipalities & $\begin{array}{l}\text { Local land use plans } \\
\text { Urban development concepts }\end{array}$ & \\
\hline
\end{tabular}

support inter-municipal cooperation but rarely intervene in a hierarchical way. Metropolitan governance is considered to be the responsibility of voluntarily co-operating local self-governments rather than a state activity. However, once created it is under legal state supervision.

The three city-states Berlin, Hamburg and Bremen are exceptional and have the same status as the Länder. In the case of Bremen and Hamburg the city-state status dates back to the $19^{\text {th }}$ century and was even strengthened after the Second World War. In fact the three city-states are strong metropolitan governments as they have the status of a sovereign state with a broad bundle of functions. However, in the cases of Hamburg and Bremen issues of cross-border cooperation emerged as early as the 1960s as dense functional interdependencies with the adjacent cities and counties of the states of Lower Saxony and Schleswig-Holstein emerged due to commuter relationships and settlement development (Blatter 2006). The same applies for Berlin and Brandenburg in the 1990s, following Germany unification.

From an institutional perspective the creation of metropolitan governance arrangements in these cases can be considered more challenging as it is no longer an issue of local self-government but an inter-governmental affair between sovereign entities in a federal state. Cooperation takes place at the level of local self-government and between state governments at the same time (see for Hamburg von Löwis 2011; Matern 2013).

\section{History}

As mentioned above, inter-municipal cooperation in metropolitan areas has quite a long tradition in Germany. At the risk of somewhat oversimplifying, we can distinguish periods where the creation of strong inter-municipal associations in metropolitan areas was widely considered as an appropriate solution from periods where metropolitan governance was strongly rejected (Brenner 2004; Blatter 2006; Heinelt/Razin/Zimmermann 2011). Besides the 1920s, the 1960s and early 1970s was a period where metropolitan solutions found acceptance (Blatter 2006; Heinz 2007). During that period integrated solutions and consolidated forms of metropolitan governance were widely accepted and partly implemented in regions like Hanover and Frankfurt/Rhine-Main. In both regions, the most consolidated organizational form of metropolitan government, the regional city, was even debated as a serious option in the late 1960s (Hanover) and early 1970s (Frankfurt/Rhine-Main). 
The non-implementation of these solutions (particularly in Frankfurt/Rhine-Main) marked the beginning of the end of the acceptance of metropolitan reforms.

The consolidated forms of metropolitan governance created in the first half of the 1970s experienced harsh resistance from local governments, and their competencies were restricted (Hanover, Frankfurt/Rhine-Main) or the associations were abolished (for instance in Brunswick in Lower Saxony). As described by Brenner (2004: 468), the 1980s were characterized by a new localism while the region was the odd man out.

The 1990s marked a return of metropolitan governance in almost all German metropolitan regions and some of the changes made in the 1980s were reversed. There are several reasons for this but the two most relevant ones relate to the consequences of German unification in the 1990s and the creation of the European single market in 1993 (Heinelt/ Razin/Zimmermann 2011; Harrison/Growe 2014). German unification resulted in domestic migration from which the bigger cities in western Germany, such as Stuttgart, benefited due to their excellent educational facilities (universities) and attractive job opportunities. This resulted in considerable pressure on the regional housing markets and in a competitive demand for land for settlement development in almost all the municipalities of the metropolitan regions. Regulation of land use was deemed necessary and regional planning was the appropriate instrument (Heinelt/Razin/ Zimmermann 2011: 195).

The creation of the European single market increased competition between cities and regions and, as a consequence, economic development and internationalization were high on the agenda of local and regional politics. One insight shared by many practitioners as well as academics was that competitiveness is created on the level of the region as a cooperative advantage (but see Lovering 1999 who claimed that this is theory led by policy or policybased evidence and not evidence-based policy). As a result, since the mid-1990s the tune of the general discourse about metropolitan regions in Germany has changed remarkably, moving from a focus on new forms of state planning and the effective provision of public services of general interest to development policies (ARL 2004; BMVBS 2006; ARL 2007; see also Blotevogel/Schmitt 2006; Harrison/Growe 2014). The pathologies of metropolitan development such as poor coordination of services and regulation of land use have lost something of their acuteness in the debate and are less frequently mentioned in the position papers issued by the influential think tanks (ARL 2004; ARL 2007).

The new agenda also had implications for governance as there was a need to ensure the inclusion of private actors. The creation of new governance arrangements in Stuttgart in 1994 and Rhine-Neckar in 2005 are cases in point. In both regions regional development agencies in the form of public-private partnerships illustrate these new forms of governance, and in both regions business actors as well as the local chambers of commerce exerted considerable influence in the course of the reforms. In addition, in both regions as well as in other regions such as Nuremberg, civic associations (Vereine) or networks were created as a sort of forum for strategic discourses about regional development (Blatter 2006).

One consequence of the governance turn was the disintegration of the previous parallel development of the German regions with regard to institutional solutions. Until 1990 different phases could be convincingly distinguished, as illustrated by Brenner (2004) or Blatter (2006). Since this time, however, we observe the parallel implementation of consolidated solutions following the institutional ideas of the 1970s, flexible forms of governance and hybrid forms. Harrison and Growe (2014: 22f.) use the term "non standard regions" as the most appropriate description of the situation. High diversity with regard to the institutional forms and the policy functions of metropolitan governance is also a result of the federal institutional framework (Heinelt/ Zimmermann 2011).

\section{Re-Scaling of Metropolitan Governance since the 1990s}

One important element of the debate on metropolitan regions in the last decade was the establishment of the "Initiative European Metropolitan Regions in Germany" (EMR) (Initiativkreis Europäische Metropolregionen, IKM) in 2001, which can be seen as a network of the largest German metropolitan regions. The initiative was launched under the supervision of the Standing Conference of Federal and State Ministers responsible for Spatial Planning (Ministerkonferenz für Raumordnung, MKRO). The EMR initiative is exceptional in the German institutional context as it is a joint initiative by the states and the federal government. However, it did not change the institutional framework but is rather a soft form of intervention that grants no substantial legal responsibilities or subsidies to metropolitan organizations; furthermore inter-municipal cooperation under the scheme is voluntary. All the $11^{1}$ members of IKM are defined by the MKRO as metropolitan areas in Germany in terms of economic, societal and cultural functions (Blotevogel/Schmitt 2006: 60 ff.; Harrison/Growe 2014: $29 \mathrm{f}$.). The metropolises are seen as the engines of economic and societal development in Germany and therefore, following the argument of IKM, need more political attention. In fact this has found conceptual recognition in several policy documents such as the national

\footnotetext{
${ }^{1}$ See http://www.deutsche-metropolregionen.org (July $8^{\text {th }}, 2016$ ).
} 
policy guidance for spatial development in 2006 and 2016 (BMVBS 2006; BMVI 2016). With regard to political organization, the 11 member regions of the network are expected to find structures of self-governance in whatever form is considered appropriate. However, as there is neither pressure nor incentive, the ambitions and results differ from region to region and institutional solutions are not pursued at the expense of other layers of local selfgovernment (counties and municipalities). It is surprising that in particular the smaller and internationally less known regions such as Nuremberg and Rhine-Neckar used this opportunity to establish new metropolitan governance structures and, therefore, have received much professional recognition for what they have created in recent years. In these smaller, less visible and polycentric regions, where a single city cannot mobilize the critical mass to become internationally competitive, it seems more likely that mutual benefits can be realized through cooperation. Actors in the bigger metropolitan regions such as Frankfurt/RhineMain were less inclined to cooperate or to sustain existing schemes of cooperation. In these larger regions the spatial delimitation also did not proceed smoothly and remained vague, complicated by the fact that jurisdictional boundaries are usually incompatible with existing functional interdependencies. In some cases such as Frankfurt/RhineMain and the wider Munich metropolitan region local identities, feelings of belonging and political rivalries also hampered cooperation (Heinelt/Razin/Zimmermann 2011). Decisions about delimitation are left to local actors in the metropolises concerned. Generally speaking, most of the EMR under question have rather large territories, reaching far beyond the borders of existing statutory planning regions (Blotevogel/Schmitt 2006).

A weakness of the EMR initiative is that the regions themselves have not been legally defined in a coherent way. It is up to the constellation of regional actors to establish a spokesperson for a metropolis as well as to decide which of the metropolitan institutions is to be an official member of the board of the EMR initiative. In some cases the statutory planning association leads the process, while in other cases new associations have been created or existing associations compete for the leadership. This lack of precise rules for the IKM membership is a disputed feature of the initiative (see Blotevogel/Schmitt 2006).

There is a strong element of prestige linked to IKM membership (see Blotevogel/Schmitt 2006: 60). In fact after the initial appointment of seven metropolitan regions in Germany in the late 1990s, several other regions competed for admission to the EMR group and seemed to consider achieving membership a success in itself (Harrison/ Growe 2014: 30). This aspect was an additional stimulus for strengthening metropolitan cooperation in some regions (e.g. the case of Nuremberg or Rhine-Neckar as mentioned above)

In the following, four cases are described to demonstrate the diversity of metropolitan governance in Germany. The selected examples furthermore all reveal what can be called a new pattern in German metropolitan governance. In all cases, different forms of cooperation emerged on different spatial scales.

\section{Cases Stuttgart, Hanover, Munich, Ruhr/Rhine- Ruhr}

\subsection{Region Stuttgart}

Signs of economic crisis in the manufacturing sector (particularly car-manufacturing) in the late 1980s and a growing awareness of intensifying competition in the Europe of the regions were the main drivers for metropolitan reform in the wider Stuttgart region (Benz 2003; Steinacher 2008). Investments in regionally relevant infrastructure (trade fair) of a scale that the core city was unable to accomplish alone, issues related to land use and the better coordination of municipal and county-level business development initiatives highlighted the need for a collaborative strategy to pool resources and develop reliable mechanisms for political coordination.

In addition, since the 1970s the core city has been surrounded by fiscally and socially rich suburban municipalities. The extremely high number of daily commuters was one of the reasons for ongoing controversy about the distribution of costs for regionally relevant public infrastructure situated in the core city (i.e. public transport, cultural facilities). The first statutory regional planning association was founded in 1972, but was incapable of tackling the growing problems and conflicts faced by the region during the 1980s and early 1990s.

As a consequence in 1994 the region of Stuttgart was founded as a two-tier system with the strong support of the prime minister of the federal state of Baden-Württemberg. Although the foundation was preceded by long negotiations and conflicts between suburban municipalities and the city of Stuttgart, the arrangement is based on the voluntary cooperation of municipalities. The association bears full responsibility for some tasks (regional planning, landscape planning, transport planning) and shares responsibility with other agencies for further tasks (waste management, economic development, transport management). The regional assembly is elected directly by the population of the region and therefore has a strong legitimacy. Especially in spatial planning, the direct legitimacy gives considerable power to the association, which can force municipalities to adapt local land-use plans by coercive means. 
This example also shows strong signs of network governance in economic development and regional marketing. Here a special purpose agency (regional development agency) with the legal form of an enterprise is owned by the regional association together with the chamber of commerce and other business actors. The regional association also does not bear full responsibility in other areas of regional development but shares the jurisdiction (e.g. for public transportation).

Based on its direct and indirect relationships with a range of public and private organizations, the association Region Stuttgart thus emerged as the central node in a differentiated network of cooperation (Benz 2003; Ludwig/ Steinacher 2008). However, it does not represent a new jurisdictional layer, and some authors (e.g. Hesse 2005: 47) consider this a failing as the association has to share some tasks with municipalities, which may cause implementation gaps.

The networked mode of governance with clear geographical boundaries has been extended by adding further scales of cooperation. Ever since 2000 there has been debate about the future scale of regional cooperation. The territory of the planning association (five counties and the city of Stuttgart) was seen to be too small as actual interdependencies grew in scale (Heinz/von Kodolitsch/Langel et al. 2004: 52). Another reason for the extension of the association is the boundary problem. The municipalities of the region are part of a planning region with strict land-use regulation whereas the municipalities beyond the border are not. The planning regulation of the latter municipalities is thus more relaxed and the peripheral municipalities inside the boundary feel disadvantaged because their neighbours outside are able to offer more sites for business development or settlement. These peripheral municipalities are therefore seeking for an extension of the border. This initiative by the peripheral municipalities coincided with the abovementioned debate about the role of large metropolitan regions in the German economy (European Metropolitan Regions) (Blotevogel/Schmitt 2006; Harrison/Growe 2014).

In fact, the enlargement of the region was proposed in 2002. The state spatial plan of the federal state of BadenWürttemberg tried to establish the functional relations between the planning association Region Stuttgart and the neighbouring counties. The idea of a regional development concept was introduced to make cooperation effective on a larger scale. Regional development concepts are very soft instruments for regional cooperation that have been en vogue in German spatial planning policy since the late 1990s (Fürst 2006). This informal instrument facilitated cooperation with some of the neighbouring planning associations under the lead of the Region Stuttgart planning association and constituted an additional scale that is now called the European Metropolitan Region Stuttgart.
However, this initiative provoked new arguments as the city of Stuttgart saw an opportunity to regain influence in metropolitan politics and to establish a kind of "municipal regionalization" with Stuttgart as the leader. Stuttgart and the planning association were in competition in this process of re-scaling and a weak compromise emerged. A committee was established to coordinate the activities of the European Metropolitan Region. The outcomes of this initiative remain vague.

\subsection{Region Hanover}

Due to its uniqueness, the " Hanover Reform" of 2001 gained much attention in the German debate about the optimal organizational form for governing metropolitan regions. The reform is considered unique as it accomplished the amalgamation of the city of Hanover, the surrounding county of Hanover and the former regional planning association (Priebs 2002; Blatter 2006: $131 \mathrm{f}$.). These kinds of amalgamations are very rare in Germany. Furthermore, several of the tasks of the government office for the region of Lower Saxony have been shifted over to the region (e.g. environmental planning). The region's population of 1.1 million inhabitants now represents $15 \%$ of the inhabitants of the German state of Lower Saxony of which Hanover with its 515,000 inhabitants is the capital.

Although the parliament of Lower Saxony established the region by law, the formation of this new regional-county can be considered the result of deliberate choices made by the affected municipalities and all political parties. This new two-tier system replaced the former system with three independent actors: the city of Hanover, the surrounding county and the planning association with a broad portfolio of tasks (transport, regional planning, landscape planning, and economic development). Although the regionalcounty has been strengthened, the municipalities have basically kept their status. The directly elected regional president is head of the administration and a directly elected metropolitan council with 84 councillors, the majority of who come from the area covered by the former county, is the source of legitimacy. The Hanover region is responsible for the provision of other social services (including hospitals) as well as for land-use planning, waste disposal, economic development, leisure facilities (like the zoo), schools for vocational training, environmental protection and the organization of public transport (Arndt/Priebs 2004). This broad bundle of functions in combination with centralized decision-making procedures and majority voting facilitates compensation measures and the sharing of costs as the budget of the region stems from allocations paid by municipalities. Therefore, the region is occasionally called a social region (Arndt/Priebs 2005: 22). 
Although the "Hanover Reform" was oriented towards enhanced effectiveness and cost saving in public service provision, the example also shows some elements of horizontal governance, e.g. decentralized networks between public and private actors, for example "hannoverimpuls", a company with limited responsibility for economic development.

Similar to Stuttgart, in Hanover further scales of cooperation have been added in recent years. The European Metropolitan Region covers a huge area in the southeast of the state of Lower Saxony. Beside the city of Hanover and the Hanover region it includes the cities of Göttingen, Brunswick and Wolfsburg (and the medium-sized cities and rural areas in-between, covering in total an area of 19,000 $\mathrm{km}^{2}$ with four million inhabitants). With regard to institutional structure, the European Metropolitan Region is much weaker than the region Hanover but also includes universities and private actors that are organized in associations. It started as an informal initiative in the 2000s, then, in 2009, an agency under private law was founded. The state government of Lower Saxony also holds a minor percentage. The agency finances projects that largely support economic development and innovation in the region. The resources available are limited compared to other regional development agencies such as the one in Stuttgart or Rhine-Neckar.

In 2010, a third scale emerged, somehow in-between the Region of Hanover and the larger European Metropolitan Region. The "Network Extended Economic Area of Hanover" (Netzwerk Erweiterter Wirtschaftsraum Hannover) gathers together 15 cities and counties adjacent to the Hanover Region (the so-called second ring) and can be considered a forum without any particular formal status. However, the network constitutes a very effective medium for communication about various topics such as tourism, regional planning and public transport. The network is part of the legacy of the EXPO 2000 city network, which was created in the course of the planning and implementation of the World EXPO 2000 that took place in Hanover in the year 2000 .

As a result of these recent developments, a three-scaled arrangement emerged in a random-evolutionary process. The three scales follow different logics of cooperation and have different purposes. While the Region of Hanover is a strong core with norm-oriented actions, the network of the second ring gathers cities and counties in a utilitarian form of cooperation and communication between public actors. The European Metropolitan Region started as a soft network with symbolic functions and now has a formalized basis also including private actors.

\subsection{Greater Munich Area}

In contrast to the regions of Hanover and Stuttgart the spatial delimitation of the region of the Munich Greater Area is rather fuzzy. The formal planning region includes 186 municipalities that are located in seven counties around the city of Munich (2.2 million inhabitants). Unlike Stuttgart and Hanover the statutory regional planning association is a less crucial part of the governance arrangement because its competence is limited to regional planning. The association has no executive tasks and no resources for implementing the regional plan. Besides the regional planning association a second voluntary planning association exists. The "Planning Association for the Wider Economic Area" (Planungsverband Äußerer Wirtschaftsraum) is a voluntary association of municipalities and counties in the form of a special-purpose organization. As it was founded in the 1950s, there was a need to develop planning expertise which was lacking especially in the small municipalities of the region. The Planning Association is a hybrid organization. On the one hand, its role is to coordinate traffic and settlement development on a voluntary basis and to articulate interests in the region and therefore take a regional perspective, but on the other hand the association is a service provider for the municipalities. In order to secure a minimum of coordination between the two associations, the executive director of the Regional Planning Association is automatically the chief executive of the "Planning Association for the Wider Economic Area".

Due to the number of initiatives operating on different spatial scales with different purposes, Munich is considered to be a fragmented metropolitan region in terms of spatial governance. In recent years many other public and private initiatives and organizations on various scales have entered the scene and changed the situation. On a voluntary basis small-scale municipal initiatives have organized projects and taken over tasks, for example in landscape protection, recreation and business development. Examples here include the Association for the Safeguarding of Regional Recreation Areas in the Counties around Munich (Verein zur Sicherstellung überörtlicher Erholungsgebiete, founded in the 1960s), the Munich North Moorland Association (Heideflächenverein Münchner Norden), and the Association Dachauer Moos (Verein Dachauer Moos) that was founded in 1995 to secure and develop the endangered green spaces in the northwest of the metropolitan area. The South Alliance (Südbündnis) was established by municipalities in the south of Munich. The alliance regards their living space as a recreational area and is attempting to develop a common settlement and traffic strategy for this subregion with a special focus on traffic problems. In 2005 two counties next to the airport and the airport company created the Airfolgsregion Erding-Freising in order to encourage 
coordinated development and to strengthen the competitiveness of the area. Further regional bodies responsible for important services such as public transport and waste management may be mentioned.

The overall direction of development concerning metropolitan governance in the Munich region is clear. The limited formal planning system in Munich furthered the creation and development of a large number of complementary initiatives with the aims of improving regional coordination and addressing problems particularly in relation to traffic, settlement development and recreation. The focus of these initiatives is project oriented and the work is based on voluntary cooperation so that they can exist only if members see a mutual benefit. However, the existence of these many initiatives - even though not of all of them are sustainable or very successful - indicates that actors at all levels in the Munich region recognize the importance of cooperation in addition to a formal planning institution.

The national initiative European Metropolitan Regions in Germany also found resonance in the Munich Greater Area. Since 1995 an initiative has existed covering a large area in southern Bavaria, the so-called Economic Space South Bavaria, Munich, Augsburg, Ingolstadt (MAI) (Wirtschaftsraum Südbayern - München-Augsburg-Ingolstadt). The overarching goal was to promote the economic development of the whole region. In 2005, the association was renamed the Greater Munich Area (GMA) in order to gain higher visibility on the international scale and to reflect the approach taken by other German metropolitan areas in the course of the EMR initiative. In October 2008, the GMA merged with the newly established European Metropolitan Region Munich (EMM) and can therefore be regarded as a forerunner of the EMM. Since January 2009 its official name is European Metropolitan Region Munich (Europäische Metropolregion München/EMM).

In contrast to all the small-scale initiatives, the creation of the European Metropolitan Region indicates another direction, namely cooperation on the metropolitan level. The territorial focus of the Munich Metropolitan Region is fuzzy, but it is possible to define a core area covering Munich, Augsburg, Ingolstadt, Landshut, Rosenheim and the adjoining counties. This area has 4.65 million inhabitants and covers a large territory in southern Bavaria. The territory is characterized by an urban core formed by the Munich planning region in the centre and surrounded by cities such as Augsburg, Ingolstadt, Rosenheim and Landshut (Breu/Jahn/Schulz 2009: 100).

The European Metropolitan Region Munich is based on voluntary cooperation between local governments, partners from the business sector, universities, research institutes and civil society organizations, and is financed through mem- bership fees. ${ }^{2}$ It provides a platform to foster, on a voluntary but committed basis, the development of the metropolitan region with the aims of increasing the attractiveness of the region and enhancing quality of life by nurturing a common responsibility for the future of the region.

\subsection{Ruhr/Rhine-Ruhr}

The Ruhr area is a much discussed case with regard to the organization of metropolitan governance (Kunzmann 2004; Schmidt 2013). One reason for this popularity is the fact that initial initiatives to establish a metropolitan governance arrangement started with the foundation of the Siedlungsverband Ruhrkohlenbezirk in 1920. The Ruhr area is considered to be a unique case because of its polycentricism and industrial past, which had a strong influence on settlement patterns and urban development - and governance.

The Siedlungsverband Ruhrkohlenbezirk was a political innovation as it was the result of voluntary cooperation between municipalities in an area characterized by rapid urbanization. As a prototype of a regional planning association in Germany based on the idea of local self-government, the association was responsible for the protection of green spaces and green corridors and for infrastructure planning, and also defined a framework for settlement development. After the Second World War the association experienced successful periods as well as more precarious ones. In 1966 the first binding regional plan for the Ruhr came into effect. Besides the statutory task of regional planning, the association was responsible for the management of regional parks and leisure facilities. Between 1975 and 1979 the government of the state of North Rhine-Westphalia decided to withdraw the association's competence for statutory regional planning, giving it to the government offices for the regions (Bezirksregierungen). These are regional branches of the state government and are not involved in local selfgovernment. The by then weakened planning association continued to exist under a new name (Kommunalverband) and was responsible for some functions granted voluntarily by the municipalities (such as management of parks and leisure facilities, master plans, collection of spatial data). As a result, in this period the association was an inter-municipal service provider but not a planning association.

In the mid-1990s a jumping of scales took place as the government of North Rhine-Westphalia defined a larger Metropolis Rhine-Ruhr in the state development plan (Danielzyk/Knapp/Schulze 2008; Blotevogel/Schulze 2010). This envisioned metropolitan area (or mega region as it is sometimes called) included not only the Ruhr area but also the major cities of Düsseldorf and Cologne and the

\footnotetext{
${ }^{2}$ EMM has more than 100 members, see http://www.metropolregion-
} muenchen.eu (July $\left.8^{\text {th }}, 2016\right)$. 
peri-urban areas in-between. In terms of sheer numbers, this Rhine-Ruhr metropolis has ca. 12 million inhabitants and considerable economic power (Blotevogel/Schmitt 2006: 67). However, with regard to the creation of a governing institution or some form of voluntary regional cooperation it must be considered a failure. The more prosperous cities (Düsseldorf, Cologne) in the south were less inclined to engage in such a large-scale institutional solution and stressed the distinctiveness of the post-industrial Ruhr area in the northeast. As a result the Rhine-Ruhr Metropolis remained a lifeless vision despite being named European Metropolitan Region Rhine-Ruhr.

Meanwhile the debates about the future political organization of the Ruhr continued and were even more dynamic. At the beginning of the 2000s discussion started again, with various suggestions ranging from the idea of the Ruhr city or Ruhrstadt (i.e. an amalgamation of the existing jurisdictions with a new name) to the creation of an agency under private law (Projekt Ruhr $\mathrm{GmbH}$ ). One may add further suggestions and initiatives highlighting different aspects of regional development und regional cooperation (i.e. the Charta Ruhr, the numerous master plans or the proposed government district Ruhr) (see Davy 2004; Kunzmann 2004; Schmidt 2013). None of these initiatives were successfully implemented in the end. Strong functional interdependencies still exist in the Ruhr but the area has, despite a common history, no common identity that might serve as a basis for enforced cooperation.

As a result of these debates and in conjunction with a political change of the state government in 2004, the planning association was strengthened again and renamed Regionalverband Ruhr (Regional Association Ruhr or RVR). In 2009 the competence for statutory regional planning was given back to the planning association, which is now also the owner of a regional development agency under private law. In 2015 the parliament of the state of North RhineWestphalia passed a new law that allows for sharing of competences between the Regional Association and the counties and cities (among others: transport). In addition, the direct election of the regional assembly will be introduced with the next local elections in 2020. Also the draft state plan for North Rhine-Westphalia now clearly distinguishes between the metropolitan region "Ruhr" and the metropolitan region "Rhineland".

Still, metropolitan governance in the Ruhr area continues to be complex and confusing: there is not a lack of intermunicipal cooperation but rather maybe too much uncoordinated cooperation. A databank of the RVR lists more than 300 inter-municipal partnerships and projects. The three universities of the Ruhr have formed an alliance, creating the research area Ruhr. Quite similar to Munich, these partnerships show different institutional formats and most of them do not cover the whole Ruhr area. This makes it difficult to judge the overall situation. Without doubt the RVR is a dominant player but there are other intermunicipal associations such the Ruhrverband, responsible for fresh water management, and the Emscher Association (Emschergenossenschaft), which has existed for more than 100 years. The Emscher Association was founded by the municipalities and large industrial enterprises in the early period of industrialization to take care of wastewater treatment and flood protection. Since the 1990s its major task has been the sanitation of the Emscher river system, which was used as an open sewer for several decades. The Emscher Association will have made investments of a total of 4.5 billion euros once the works are finished (Emschergenossenschaft 2016). The association is also involved in the management of the Emscher Landscape Park (together with the RVR) and started some urban and regional development projects as the River Emscher flows through several cities in the Ruhr. Private actors have formed their own initiatives but are not included in the same way as in the European Metropolitan Region Munich (EMM) or in Stuttgart. The most important initiative is the Initiativkreis $R u h r$, which is both an association (Verein) and a limited liability company or agency $(\mathrm{GmbH})$ with 65 members (largely enterprises that have an interest in producing a club good).

The situation in the Ruhr is best described by the term "fragmegration" introduced by political scientists seeking a proper description for European multi-level governance (Hooghe/Marks 2003: 234). Although a certain degree of integration and coordinated action can be observed, fragmentation is still considerable (Schmidt 2013). There is more than one logic of interaction and there is more than one institution so that many stand side by side with different actors, different purposes and different rules for cooperation (Davy 2004).

\section{Conclusion: Uneven re-scaling in a federal state}

Metropolitan governance in Germany is realized in various policy sectors and on various scales. The initiatives of the 1970s focused on planning issues, public transport and other public services. However, there are only a few cases (Hanover, Stuttgart) where strong multi-purpose associations have been created with responsibility for a larger portfolio on the spatial scale of city regions. In particular the combination of transport planning, public transport management and regional planning is deemed highly relevant but is realized only in isolated cases. In other regions several single-purpose associations exist side by side (Hoyler/ Freytag/Mager 2006; Schmidt 2013). During the new regionalism period of the 1990s new actors, governance forms and scales and new functions were added. However, the new 
regionalism as well as the initiative European Metropolitan Regions (EMR) with a focus on economic development and internationalization overwhelmed the debate and disguised the progress made in some regions in the governance of public services and planning.

The emergence of a new spatial scale as a result of the EMR initiative since the late 1990s can be described as a pattern involving the combination of a strong institutional core on a smaller scale (usually planning associations in city regions, in part created in the 1970s) and softer forms of governance on larger scales (metropolitan regions). This pattern can be observed in Hanover where a three-scaled constellation has been established, as well as in Stuttgart and Munich. However, the new multi-scaled arrangements in German metropolitan regions are not the result of careful institutional design but are contingent on actor constellations and incentives provided by other governmental layers. This implies that the arrangements are unstable and may disappear. In accordance with the academic debate, we see scales as social and political constructions that are not necessarily institutionalized in a formal way nor follow purely functionalist explanations (Keil/Mahon 2009: 15). However, the re-scaling of functions needs to be considered against the parallel trends of decentralization and regionalization that are observable in Germany as well as in other countries (Baldersheim/Rose 2010; Kuhlmann/Wayenberg 2016). The creation of European Metropolitan Regions invents a new scale but does not necessarily involve the downscaling of political or administrative functions. Compared to the 1970s, various policy sectors and scales are affected and new actors, purposes, contents and organizational structures have been added. The introduction of the European Metropolitan Regions fostered not only a focus on economic development but also - at least in some regions limited upscaling. Although the new and - in terms of spatial research - larger scales did not come at the expense of smaller scales the process is characterized by struggle (see the cases of Stuttgart and Rhine-Ruhr). We consider this process a further differentiation of regional policies. Differentiation refers not only to the emergence of various regional scales (city regions, metropolitan regions, sectoral arrangements) but also to the motivation of metropolitan policies. Although competitiveness was the main driver for the European Metropolitan Regions we find other motivations such as sustainable development and better public transport on smaller scales of governance (i.e. city regions).

In the German case, parallel strategies of administrative decentralization and the regionalization of development policies and sustainability strategies create new layers of policymaking on different regional scales. We may call this differentiation of scaled metropolitan policies "embedded regionalization". This renders the notions "metropoli$\tan$ region" or "city region" somewhat fuzzy and, at least in some of the German regions, the result is overcrowded policymaking. ${ }^{3}$

Germany represents a case of diverse metropolitan governance and shows a constant dynamic that results in incremental changes in most of the metropolitan regions. The reason for this diversity is German federalism and the strong and widely supported institutional idea of local self-government. Regional actors, public and private, are expected to form institutional solutions on the basis of voluntary selfcoordination. However, actors do not find a consensus in all metropolitan regions and we also observe a variety of governance forms that emerge out of regional contexts (public-public associations, public-private agencies, networks). The absence of targeted national regulation and universal formats, therefore, is in contrast to other European countries (see contributions on UK (Shaw/Tewdwr-Jones 2017), France (Geppert 2017) and Italy (Fedeli 2017)).

The disadvantage of this absence of nationally coordinated metropolitan policies may be seen in the fact that institutional misfit, lack of cooperation or fragmentation can be observed in the majority of German metropolitan regions (Hoyler/Freytag/Mager 2006; Heinelt/Razin/Zimmermann 2011), which may result in problems of democratic legitimacy (Zimmermann 2014). Comprehensive solutions have only been found in a few regions such as Hanover and Stuttgart while others, such as the Ruhr (or Rhine-Ruhr), demonstrate more incremental progress.

\section{References}

ARL - Akademie für Raumforschung und Landesplanung (2004): Strategien für Großstadtregionen im 21. Jahrhundert. Hannover. = Arbeitsmaterial der ARL 309.

ARL - Akademie für Raumforschung und Landesplanung (2007): Metropolregionen - Innovation, Wettbewerb, Handlungsfähigkeit. Hannover. = Positionspapier aus der ARL 71 .

Arndt, M.; Priebs, A. (2005): Region Hannover - eine Zwischenbilanz zur Mitte der ersten Wahlperiode. In: Der Städtetag 2, 20-23.

Baldersheim, H.; Rose, L. (eds.) (2010): Territorial Choice. The Politics of Boundaries and Borders. Basingstoke.

Benz, A. (2003): Regional Governance mit organisatorischem Kern. Das Beispiel der Region Stuttgart. In: Informationen zur Raumentwicklung 8/9, 505-512.

Blatter, J. (2006): Geographic scale and functional scope in metropolitan governance reform: theory and evidence from Germany. In: Journal of Urban Affairs 28, 2, 121-150.

Blotevogel, H.H.; Schmitt, P. (2006): 'European Metropolitan Regions' as a new discursive frame in strategic spatial planning and policies in Germany. In: Die Erde 137, 1-2, 55-74.

Blotevogel, H.H.; Schulze, K. (2010): 1 oder 2 oder 3? Zur Konstituierung möglicher Metropolregionen an Rhein und Ruhr. In: Raumforschung und Raumordnung 68, 4, 255-270.

BMVBS - Bundesministerium für Verkehr, Bau und Stadtentwicklung (2006): Leitbilder und Handlungsstrategien für die Raumentwicklung in Deutschland. Berlin.

\footnotetext{
${ }^{3}$ I borrow this term from Richardson and Jordan (1983). Using the notion they describe a situation where an increased number of interest groups make it difficult to reach agreed decisions.
} 
BMVI - Bundesministerium für Verkehr und digitale Infrastruktur (2016): Leitbilder und Handlungsstrategien für die Raumentwicklung in Deutschland. Berlin.

Brenner, N. (2004): Urban governance and the production of new state spaces in western Europe, 1960-2000. In: Review of International Political Economy 11, 3, 447-488.

Brenner, N. (2009): A thousand leaves: notes on the geographies of uneven spatial development. In: Keil, R.; Mahon, R. (eds.): Leviathan Undone? Towards a Political Economy of Scale. Vancouver, 27-50.

Breu, C.; Jahn, B.; Schulz, H. (2009): Projektbezogene Governance in der Europäischen Metropolregion München (EMM). In: Ludwig, J.; Mandel, K.; Schwieger, C.; Terizakis, G. (eds.): Metropolregionen in Deutschland. Baden-Baden, 98-110.

Danielzyk, R.; Knapp, W.; Schulze, K. (2008): "metropoleruhr" oder "TripelMetropolis Rhein-Ruhr"? In: Informationen zur Raumentwicklung 9/10, 549-562.

Davy, B. (2004): Die neunte Stadt. Wilde Grenzen und Städteregion Ruhr 2030. Wuppertal.

Emschergenossenschaft (2016): Daten und Fakten zum Emscherumbau. http://www.abwasserkanal-emscher.de/de/abwasserkanalemscher/projektinformationen/daten-und-fakten.html (13.07. 2016).

Fedeli, V. (2017): Metropolitan Governance and Metropolitan Cities in Italy: Outdated Solutions For Processes of Urban Regionalisation? In: Raumforschung und Raumordnung 75, 3.

Fürst, D. (2005): Metropolitan governance in Germany. In: Heinelt, H.; Kübler, D. (eds.): Metropolitan Governance, Capacity, Democracy and the Dynamics of Place. London, 151-168.

Fürst, D. (2006): The Role of Experimental Regionalism in Rescaling the German State. In: European Planning Studies 14, 7, 923-938.

Fürst, D.; Klinger, W.; Knieling, J.; Mönnecke, M.; Zeck, H. (1990): Regionalverbände im Vergleich: Entwicklungssteuerung in Verdichtungsräumen. Baden-Baden. = Schriften zur kommunalen Wissenschaft und Praxis 4.

Geppert, A. (2017): Vae victis! Spatial Planning in the Rescaled Metropolitan Governance in France. In: Raumforschung und Raumordnung 75, 3.

Harrison, J.; Growe, A. (2014): From places to flows? Planning for the new 'regional world' in Germany. In: European Urban and Regional Studies 21, 1, 21-41.

Heinelt, H.; Razin, E.; Zimmermann, K. (2011): Metropolitan Governance. Different paths in contrasting contexts: Germany and Israel. Frankfurt am Main, Chicago.

Heinelt, H.; Zimmermann, K. (2011): 'How Can We Explain Diversity in Metropolitan Governance within a Country?' Some Reflections on Recent Developments in Germany. In: International Journal of Urban and Regional Research 35, 6, 1175-1192.

Heinz, W. (2007): Inter-local cooperation in Germany. The mismatch between existing necessities and suboptimal solutions. In: Hulst, R.; van Montfort, A. (Hrsg.): Inter-municipal Cooperation in Europe. Dordrecht, 91-115.

Heinz, W.; von Kodolitsch, P.; Langel, N.; Reidenbach, M. (2004): Interkommunale Kooperation in baden-württembergischen Stadtregionen: Stuttgart, Karlsruhe und Freiburg. Berlin. = Difu-Beiträge zur Stadtforschung 38.

Hesse, J.J. (2005): Modelle der Stadt-Umland-Organisation in der Bundesrepublik Deutschland. Vergleichsanalyse und Schlussfolgerungen für den Raum Saarbrücken. Berlin.
Hooghe, L.; Marks, G. (2003): Unraveling the Central State, but How? Types of Multi-Level Governance. In: American Political Science Review 97, 2, 233-243.

Hoyler M.; Freytag T.; Mager C. (2006): Advantageous Fragmentation? Reimagining Metropolitan Governance and Spatial Planning in Rhine-Main. In: Built Environment 32, 2, 124-136.

Keil, R.; Mahon, R. (2009): Introduction. In: Keil, R.; Mahon, R. (eds.): Leviathan Undone? Towards a Political Economy of Scale. Vancouver, 3-23.

Krukowska, J.; Lackowska, M. (2017): Metropolitan Colours of Europeanization. Institutionalization of Integrated Territorial Investment Structures in the Context of Past Cooperation in Metropolitan Regions. In: Raumforschung und Raumordnung 75, 3.

Kuhlmann, S.; Wayenberg, E. (2016): Institutional impact assessment in multi-level-systems: conceptualizing decentralization effects from a comparative perspective. In: International Review of Administrative Science 82, 2, 233-254.

Kunzmann, K. (2004): The Ruhr in Germany. A laboratory for regional governance. In: Kunzmann, K. (ed.): Reflexionen über die Zukunft des Raumes. Dortmund, 97-113. = Dortmunder Beiträge zur Raumplanung, Blaue Reihe 111.

Lovering, J. (1999): Theory led by policy: the inadequacies of the 'new regionalism' (illustrated from the case of Wales). In: International Journal of Urban and Regional Research 23, 2, 379-395.

Ludwig, J.; Steinacher, B. (2008): Kräfte bündeln in der Metropolregion Stuttgart. In: Ludwig, J.; Mandel, K.; Schwieger, C.; Terizakis, G. (eds.): Metropolregionen in Deutschland. Baden-Baden, 169-183.

Matern, A. (2013): Mehrwert Metropolregion. Stadt-Land-Partnerschaften und Praktiken der Raumkonstruktion in der Metropolregion Hamburg. Bielefeld.

Priebs, A. (2002): Die Bildung der Region Hannover und ihre Bedeutung für die Zukunft stadtregionaler Organisationsstrukturen. In: Die Öffentliche Verwaltung 55, 4, 144-151.

Richardson, J.J.; Jordan, A.G. (1983): Overcrowded Policymaking: Some British and European Reflections. In: Policy Sciences 15, 3, 247-268.

Schmidt, M. (2013): Regional Governance und Infrastruktur. Kooperationen in der Wasserver- und Abwasserentsorgung am Beispiel der Stadtregionen Frankfurt/M, Berlin und Ruhr. Detmold.

Shaw, K.; Tewdwr-Jones, M. (2017): "Disorganised Devolution": Reshaping Metropolitan Governance in England in a Period of Austerity. In: Raumforschung und Raumordnung 75, 3.

Steinacher, B. (2008): Die Europäische Metropolregion - Analyse und praktische Erfahrungen. In: Basten, L. (ed.): Metropolregionen Restrukturierung und Governance. Dortmund, 21-36.

Swyngedouw, E. (2004): Globalisation or 'Glocalisation'? Networks, Territories and Rescaling. In: Cambridge Review of International Affairs 17, 1, 25-48.

von Löwis, S. (2011): Governance between Stability and Change - the Case of the Metropolitan Region Hamburg (MRH). In: Schrenk, M.; Popovich, V.V.; Zeile, P. (Hrsg.): Proceedings REAL CORP 2011, 18-20 May 2011, Essen. Schwechat, 375-389.

Zimmermann, K. (2014): Democratic Metropolitan Governance: Experiences in five German Metropolitan Regions. In: Urban Research \& Practice 7, 2, 182-199.

Zimmermann, K.; Getimis, P. (2017): Rescaling of Metropolitan Governance and Spatial Planning in Europe: an Introduction to the Special Issue. In: Raumforschung und Raumordnung 75, 3. 